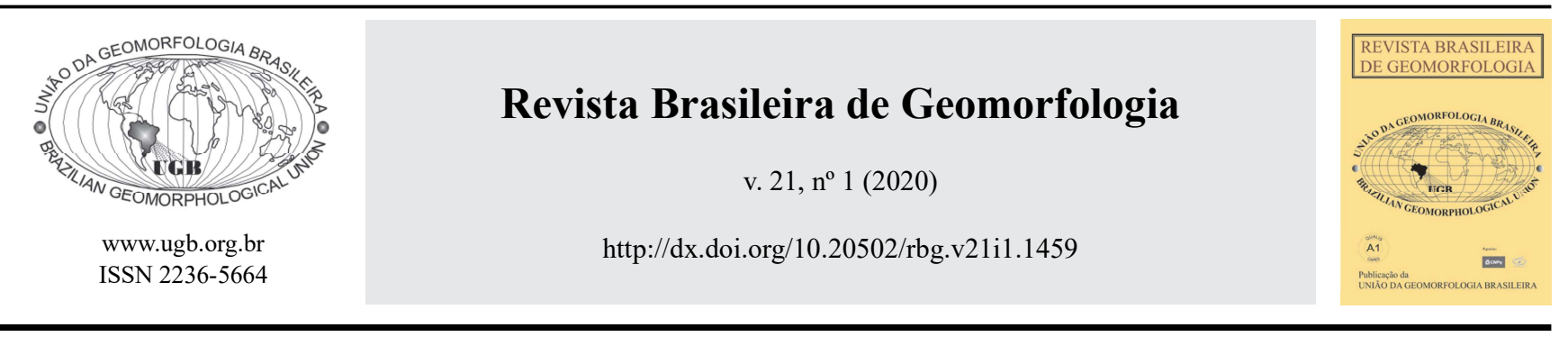

\title{
LITORAL DO ESTADO DO PIAUÍ: PROPOSTA DE COMPARTIMENTAÇÃO
}

\section{COAST OF THE STATE OF PIAUÍ: PROPOSAL FOR COMPARTMENTATION}

\author{
Carlos Henrique Santos da Silva \\ Instituto Maranhense de Estudos Socioeconômicos e Cartográficos-IMESC \\ Av. do Vale, Ed. Zircônio, $1^{\circ}$ Andar, São Luís, Maranhão. CEP: 65075-820. Brasil \\ ORCID: 0000-0003-3935-2479 \\ Email: carlos-henriquess@hotmail.com
}

Iracilde Maria de Moura Fé Lima

Departamento de Geografia, Universidade de Federal do Piaui Campus Universitário Ministro Petrônio Portella, s/n, Teresina, Piauí. CEP: 64049-550. Brasil

ORCID: 0000-0003-3936-180X

Email: iracildefelima@ufpi.edu.br

\begin{tabular}{l} 
Informações sobre o Artigo \\
\hline Recebido (Received): \\
14/06/2018 \\
Aceito (Accepted): \\
21/06/2019
\end{tabular}

\section{Palavras-chave:}

Compartimentação do Litoral Piauiense; Processos Morfodinâmicos; Gerenciamento Costeiro; Dinâmica Costeira.

\section{Keywords:}

Compartmentation of the piauien-se coast; Morphodynamic processes; Coastal management; Coastal dynamics.

\section{Resumo:}

O presente trabalho apresenta uma proposta de compartimentação do litoral do Estado do Piauí, tendo como base o alinhamento da costa, a predominância de materiais e a tipologia de formas litorâneas, bem como os processos morfodinâmicos locais. Essa compartimentação consiste numa referência espacial em escala estadual, o que possibilita orientar o uso da terra e tomadas de decisões para efeito de gerenciamento, por identificar unidades que apresentam relativa homogeneidade ambiental, conforme suas características morfológicas e tipos de processos nelas atuantes. Para que esta pesquisa fosse realizada, fez-se uma revisão da literatura, trabalhos de campo e observações de imagens Landsat e Google Earth, utilizando-se técnicas de geoprocessamento. Tendo em vista que essa faixa do litoral do Piauí tem sido classificada como parte de grandes compartimentos que setorizam o litoral brasileiro, para efeito de maior conhecimento de suas características ambientais e gerenciamento, este estudo propõe sua classificação em três compartimentos locais: Litoral Deltaico, Litoral Dunoso e Litoral Estuarino.

\footnotetext{
Abstract:

The present work presents a proposal of compartmentation of the coast of Piauí State, based on the alignment of the coast, the predominance of materials and the typology of coastal forms, as well as the local morphodynamic processes. This compartmentation consists of a spatial reference at the state level, which makes it possible to guide land use and decision making for management purposes, by
} 
identifying units which present relative environmental homogeneity, according to their morphological characteristics and the types of processes involved. In order to carry out this research, a review of the literature, field works and observations of images Landsat and Google Earth was made, using techniques of geoprocessing. Considering that this stretch of the coast of Piauí has been classified as part of large compartments that sectorize the Brazilian coast, for a better knowledge of its environmental characteristics and management, this study proposes its classification in three local compartments: Deltaic Coast, Dune Coast and Estuarine Coast.

\section{Introdução}

Variadas abordagens de compartimentação têm sido utilizadas em vários países como um meio de melhorar o gerenciamento costeiro. Estes utilizam critérios diversos, que vão desde padrões de sedimentação e erosão, análises de variância, relação entre aspectos geológicos, geomorfológicos, oceanográficos, climáticos e ambientais, até geoindicadores.

Nas últimas décadas a abordagem de compartimento de sedimentos, em várias escalas, tem sido bastante utilizada nos Estados Unidos, Europa e principalmente na Austrália, decorrente do melhor entendimento da mobilidade de sedimentos e transporte ao longo da costa, vinculada a estruturas geológicas e processos costeiros (DAVIES, 1974; THOM et al., 2018). Outra proposta interessante, refere-se à utilização do método de geoindicadores, como base para a definição e avaliação de compartimentos, que é aplicado em países da América Central, principalmente em Porto Rico (JACKSON JÚNIOR et al., 2009). No Brasil, variadas compartimentações foram utilizadas ao longo das décadas, reflexo da configuração, morfologia e extensão do litoral brasileiro.

A configuração e a morfologia recentes do litoral brasileiro resultam de longa interação entre processos ligados a eventos tectônicos, climáticos e oceanográficos, além das flutuações do nível relativo do mar (TESSLER; GOYA, 2005). Processos continentais diversos atuam nos sistemas erosivos e deposicionais das faixas costeiras, integrando-se a processos oceânicos através do regime de ondas e transporte de sedimentos paralelamente à linha de costa, além da amplitude das marés e seu potencial geomórfico (TORRES et al., 2012).

Assim, a identificação de compartimentos geomorfológicos, a partir de suas características morfológicas e dos processos neles atuantes, torna-se importante como passo inicial para a sistematização dos conhecimentos existentes. A sua análise, envolvendo observações sobre a morfodinâmica e a integração de informações em nível multidisciplinar, torna-se importante para fins de identificação de segmentos de maior vulnerabilidade, planejamento e gerenciamento dessas zonas costeiras (MUEHE, 2005; 2012).

O litoral brasileiro apresenta paisagens diversificadas, alongando-se por grandes extensões segmentadas em direções gerais predominantes de Leste-Oeste e Norte-Sul. Refletem condições de climas semiárido, tropical e subtropical, tornando importante a sua compartimentação para maior entendimento da morfologia e dinâmica de cada um de seus setores, como destaca Torres et al. (2012).

Diversos são os estudos que compartimentaram o litoral brasileiro. Gabaglia (1916) é identificado como pioneiro na sistematização dos conhecimentos existentes até então. Propôs uma classificação dessa faixa costeira, definindo seis compartimentos: Costa de Mangues (do cabo Orange ao cabo Norte); Costa de Estuário (região do baixo Amazonas); Costa Mista (da ponta da Tijoca ao delta do Parnaíba); Costa Dunosa (do delta do Parnaíba ao cabo de Santo Antônio); Costa Concordante (do cabo de Santo Antônio à barra do Araranguá) e Costa Arenosa (da barra do Araranguá à foz do Arroio Chuí) (DINIZ et al., 2016 apud GABAGLIA, 1961).

Uma década depois, Carvalho (1927) fez a compartimentação do litoral brasileiro em quatro grandes zonas fisiográficas, considerando como critérios os condicionantes tectônicos. Essas zonas foram nomeadas como: Costa Quaternária do Norte (do Amapá até o Maranhão); Costa Terciária (do Piauí ao Cabo Frio); Costa Eruptiva (do Cabo Frio até Laguna) e Costa Quaternária do Sul (da Laguna ao Chuí).

Atribuindo aos elementos climáticos e oceanográficos maior importância que aspectos continentais, Silveira (1964) propôs outra divisão compartimentando o litoral brasileiro em cinco grandes complexos litorâneos: Litoral Amazônico ou Equatorial (da foz do rio Oiapoque ao Maranhão Oriental); Litoral Nordestino ou das Barreiras (do Maranhão Oriental à Baía de Todos os Santos); Litoral Oriental (da Baía de Todos os 
Santos ao Cabo Frio); Litoral Sudeste ou das Escarpas Cristalinas (do Sul do Espírito Santo ao Cabo de Santa Marta) e o Litoral Meridional ou Subtropical (de Laguna ao Arroio Chuí) (TESSLER; GOYA, 2005 apud SILVEIRA, 1968).

Dando ênfase aos condicionantes geológico-geomorfológicos, oceanográficos e climáticos Muehe (1998) subdividiu as paisagens litorâneas brasileiras nos seguintes compartimentos: Litoral Norte (do Cabo Orange a Mangues Secos); Litoral Nordeste (dos Mangues Secos a Salvador); Litoral Oriental (de Salvador a Cabo Frio); Litoral Sudeste (de Cabo Frio ao Cabo de Santa Marta) e Litoral Sul (do Cabo de Santa Marta à Barra do Chuí) (DINIZ et al., 2016).

Ab'Sáber (2001), tendo por base fatores geomorfológicos, paisagísticos e fitogeográficos, em um primeiro nível de setorização do litoral do Brasil, reconhece seis grandes compartimentos, dentre eles o Litoral Setentrional do Nordeste. Este corresponde ao trecho entre o Nordeste do Maranhão e o Leste de Natal-RN, no qual incluiu o litoral do Piauí.

Muehe (2012) em estudo mais recente realizou sua subdivisão em setores de menor extensão. Nessa nova classificação o trecho litorâneo do Piauí obteve maior destaque, em relação às classificações anteriores, ao compor um segmento formado também com uma parte do litoral dos estados do Maranhão e do Ceará. Esse subsetor é destacado pela dominância dos depósitos sedimentares do Grupo Barreiras, à frente dos quais se desenvolveram numerosos campos de dunas, alimentados pelos sedimentos provenientes da plataforma continental interna carreados pela drenagem até o litoral, sofrendo intervenção das ondas, que transportam os sedimentos para as praias, de onde são remobilizados pelo vento. Feições morfológicas aí destacadas são representadas pelo extenso campo de dunas dos Lençóis Maranhenses, na extremidade oeste do compartimento e pelo delta do rio Parnaíba.

Em 2016, Diniz e Oliveira propuseram a compartimentação do litoral do Nordeste brasileiro, levando em consideração principalmente a forma geométrica da linha de costa, dividindo o litoral em mesoescala e classificando-o em Costa Semiárida Brasileira - CSB (Costa dos Deltas, Costa das Dunas e Costa Branca) e Costa dos Recifes -CR (Costa Mista de Dunas e Falésias, Costa das Falésias e Costa dos Cordões Arenosos). O compartimento que inclui o litoral do Piauí está loca- lizado na CSB, mais precisamente na Costa dos Deltas,

O estudo de Cavalcanti (2000), embora não se refira à subdivisão do litoral do Piauí em relação à compartimentação do litoral brasileiro, a exemplo de outros estados brasileiros (FEITOSA; TROVÃO, 2006; TEIXEIRA; SOUZA FILHO, 2009), foi o primeiro a se referir a uma classificação local. Utilizou como base a configuração do alinhamento e a sua diferenciada dinâmica natural, estabelecendo três setores distintos: Litoral Ocidental (da Baía das Canárias a Luís Correia); Litoral Central (de Luís Correia a Macapá); e Litoral Oriental (Macapá à Barra do Timonha).

Assim, buscando incluir o detalhamento do litoral do Piauí na discussão sobre os compartimentos que setorizam o litoral brasileiro, iniciou-se este estudo com uma ampla revisão da literatura sobre esse tema. Realizaram-se também trabalhos de campo e análises dos dados com o auxílio do geoprocessamento. Nesta análise foram considerados o alinhamento da costa, a predominância de materiais e tipologia de formas litorâneas, bem como os processos morfodinâmicos locais.

Como conclusão apresentou-se uma proposta de classificação do Litoral do Piauí em três compartimentos: Litoral Deltaico, Litoral Dunoso e Litoral Estuarino.

\section{Materiais e Métodos}

A identificação dos compartimentos foi efetuada através de complexas e intricadas relações com: 1) alinhamento geral da linha de costa; 2) tipo climático predominante; 3) aspectos geológicos e geomorfológicos predominantes na faixa litorânea local, neste caso: delta, campos de dunas, estuários e praias; e 4) aspectos oceanográficos (correntes, ondas e marés).

$\mathrm{O}$ alinhamento da costa influencia diretamente os elementos climáticos e como consequência, os oceanográficos, sendo esta característica um dos critérios principais de delimitação de compartimentos. Sua orientação e trechos que se apresentam côncavos, convexos ou retilíneos em relação ao Oceano Atlântico, influenciam nos processos costeiros e atmosféricos predominantes, sendo esta análise que determina a relação entre o maior ou menor transporte longitudinal e a direção que os ventos sopram do oceano para o continente (DINIZ; OLIVEIRA, 2016).

O alinhamento da costa do Piauí apresenta sentidos diferenciados: da Baía das Canárias a desembocadura do 
rio Igaraçu em Luís Correia segue o sentido SE-NE, deste à ponta do Anel na desembocadura dos rios Cardoso e Camurupim tem o sentido SE-NE, e daí à Barra dupla dos rios Ubatuba e Timonha tem o sentido W-E.

Os aspectos geológicos, geomorfológicos, climáticos e oceanográficos, são parâmetros importantes na determinação da configuração e tipo de costa, estes foram obtidos junto ao Serviço Geológico do Brasil (CPRM) e nas obras de Lima (1987); Lima et al. (2010); Cavalcanti (2000); Paula (2013); Sousa (2015); e Paula et al. (2016).

Também de importância fundamental para a identificação e delimitação dos compartimentos foram: 1) levantamento bibliográfico da área de estudo e de compartimentações realizadas no litoral do Brasil; 2) levantamento cartográfico da área de estudo; 3) trabalho de campo; e 4) análise, intepretação e elaboração de mapas dos compartimentos através de imagens de satélite.

O levantamento da bibliografia foi realizado nas bibliotecas da Universidade Federal do Piauí(UFPI), Universidade Estadual do Maranhão (UEMA) e da Universidade Federal do Maranhão (UFMA). Foram feitas consultas em anais de eventos, site, artigos, obras e documentos que abordam temas referentes a presente pesquisa.

Em laboratório fez-se levantamento cartográfico, com observação e análise dos mapas de Geologia (CPRM, 2006), Geomorfologia (LIMA, 1987), Folhas sistemáticas planialtimétricas de PARNAÍBA: MI 554/SA. 2A-Y-A-IV (1978) e BITUPITÁ: MI-555/SA. 2A-Y-A-V (1979). DSG/SUDENE. Escala: 1:100.000 (BRASIL, 1978b, 1979) e visualização de imagens do software Google Earth.

Para corroborar as informações obtidas através da análise de cartas e mapas, no ano de 2016 foi realizado um trabalho de campo em todo o litoral do Piauí, afim de realizar reconhecimento de feições e visualização das características morfológicas, geológicas, da dinâmica costeira e do uso e ocupação da costa. Também foram realizados registros através de fotografias.

Para elaboração dos mapas de compartimentação do litoral do Piauí, inicialmente realizou-se uma análise, interpretação e integração de informações existentes as imagens de satélite, e posteriormente foram elaborados os mapas de cada compartimento do litoral piauiense.

As imagens foram adquiridas no site do Instituto Nacional de Pesquisas Espaciais - INPE, do satélite LandSat 8, sensor OLI, com data de aquisição de 06/08/ 2015. No software ArcGis 10.2, foram utilizadas as bandas 3, 4 e 5, para compor a banda colorida (RGB) com $30 \mathrm{~m}$ de resolução espacial. Posteriormente esta foi fusionada com a banda 8 (pancromática) para se obter uma imagem com resolução espacial de 15 metros.

\section{Resultados e Discussão}

O litoral do Piauí se localiza na porção norte desse estado, nordeste setentrional do território brasileiro. Apresenta $66 \mathrm{~km}$ referente a linha de costa, com direção geral de Oeste-Leste, iniciando-se na baía das Canárias, no Delta do rio Parnaíba, fazendo o limite com o Estado do Maranhão e se estende até a baía onde desagua o rio Ubatuba, no limite com o Ceará (Figura 1). No sentido norte-sul, essa faixa costeira encontra-se entre o Oceano Atlântico e os Tabuleiros Litorâneos, formados pelo Grupo Barreiras e também por afloramentos rochosos pré-Cambrianos (BAPTISTA, 1981; LIMA, 1987).

A base geológica da costa piauiense corresponde, predominantemente, às coberturas cenozoicas e abrangem os períodos: Terciário e Quaternário. O Terciário está representado pela Formação Barreiras, composta por sedimentos arenoargilosos, não ou pouco litificados. Apresentam coloração ora avermelhada, ora creme ou amarelada, muitas vezes com aspecto mosqueado, mostrando horizontes conglomeráticos e níveis lateríticos, sem cota definida, em geral, associados à percolação de água subterrânea. O período Quaternário está representado por depósitos sedimentares de dunas fixas e móveis e também de sedimentos aluvionares (LIMA; BRANDÃO, 2010 apud BRANNER, 1902).

Nessa área ocorrem, ainda, afloramentos de rochas cristalinas como granitos e diabásios no extremo noroeste, na Ilha Grande de Santa Isabel, como também na área leste, próximo ao limite com o Ceará (BRASIL/ CPRM, 2006).

O clima característico da área de estudo é o Aw' - Tropical Chuvoso (quente e úmido com chuvas de verão e outono) de acordo com a proposta de Köppen (CAVALCANTI, 2000). Apresenta duas estações bem definidas, uma chuvosa, com concentração de chuvas no primeiro semestre, com distribuição média anual de aproximadamente $1300 \mathrm{~mm}$ e outra seca, predominante no segundo semestre. As temperaturas médias mensais variam entre $26,5^{\circ} \mathrm{C}$ e $27,5^{\circ} \mathrm{C}$ e os alísios de nordeste, são os principais tipos de ventos da área de estudo, apresentando velocidade média entre 0,7 e $4,4 \mathrm{~m} / \mathrm{s}$ (PAULA, 2013). 


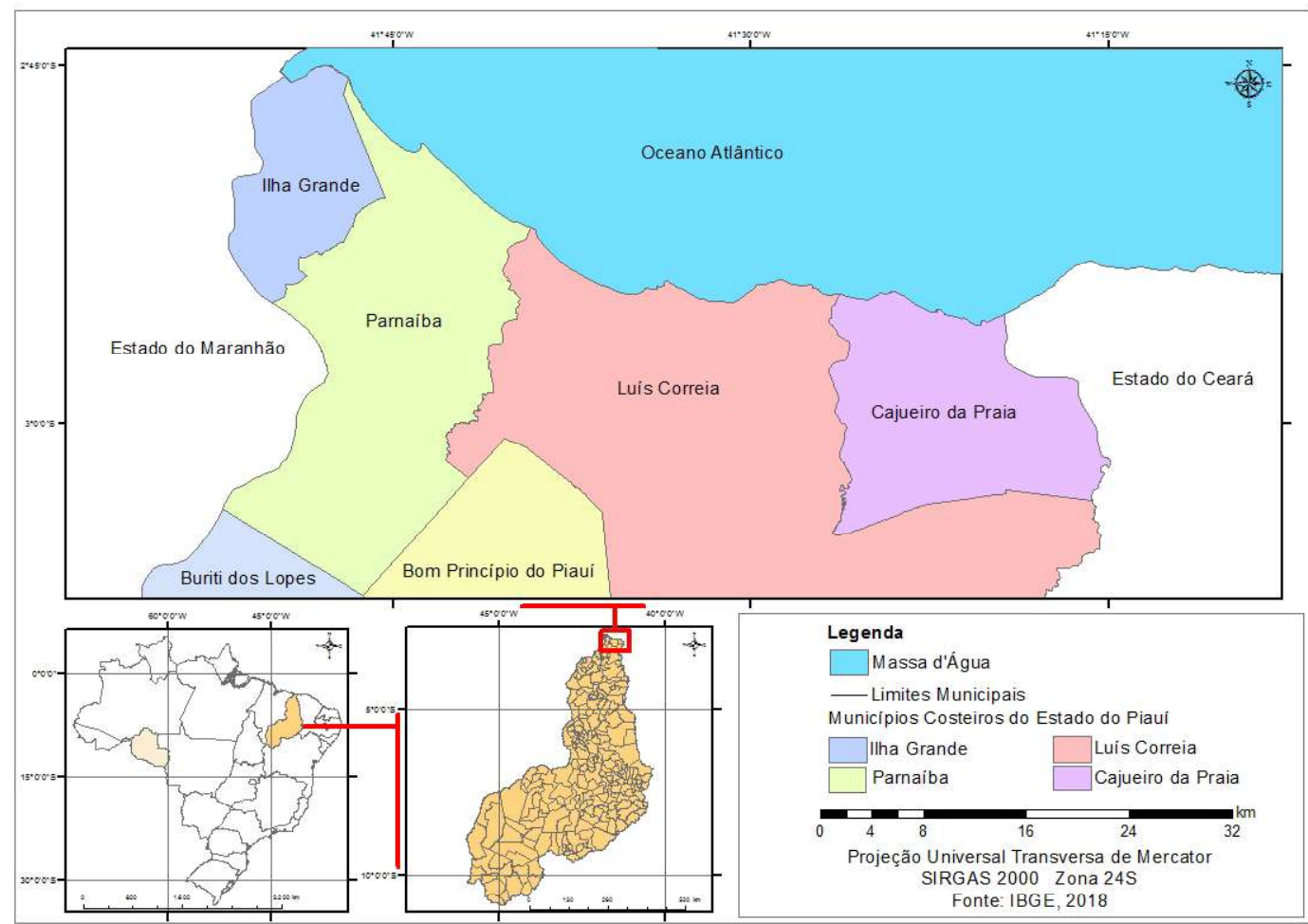

Figura 1 - Localização da área de estudo. Fonte: Elaborado pelos autores (2019).

O litoral do Piauí é regido pela elevada ocorrência de mesomarés com amplitude de 3,7 metros de variação. Essas marés são do tipo semidiurna, que seguem o padrão normal de marés, possuindo eventualmente duas preamares e duas baixa-mares no intervalo de 1 dia lunar, ou seja, 24h 50min. Apresenta um intervalo de tempo entre a preamar e a baixamar com pouco mais de 6 horas (PAULA, 2013).

As ondas apresentam valores médios de $0,83 \mathrm{~m}$ durante a estação seca e 0,64 m na estação chuvosa. Os valores mais altos na estação seca estão relacionados com a maior velocidade dos ventos durante este período. Essas ondas atuantes no litoral do Piauí chegam principalmente do norte-nordeste $\left(340-10^{\circ}\right)$. Perto da costa são afetadas por rochas submersas, como o promontório de Pedra do Sal e recifes de arenito, causando a atenuação das ondas e a refração-difração. Na maré alta, as ondas mais altas atingem a face da praia, causando retrogradação de médio e longo prazo da linha de costa, no qual surgem pequenos embaiamentos. O período de pico de onda varia entre 5,8 e 12,4 s. Mais de $70 \%$ das ondas apresentam período entre 6 e $9 \mathrm{~s}$ prevalecendo durante a estação chuvosa e $90 \%$ do tempo durante a estação seca. As ondas swell ( $>9 \mathrm{~s}$ período) foram mais significativas durante a estação chuvosa, chegando apro- ximadamente $25,7 \%$ do tempo (PAULA et al., 2016).

A corrente longitudinal é considerada o elemento predominantemente responsável pelo deslocamento de sedimentos na zona costeira. Assim, a sua variação é calculada a partir dos dados de incidência e altura das ondas na arrebentação, onde valores com variação de $1,02 \mathrm{~m} / \mathrm{s}$ (máxima para leste) a $8,87 \mathrm{~m} / \mathrm{s}$ (máxima para oeste) de velocidade dessa corrente foram encontrados, mantendo-se uma corrente média de $1,23 \mathrm{~m} / \mathrm{s}$ (PAULA et al., 2016). Além desse tipo de transporte como resultante, ainda existe o transporte transversal que carrega os sedimentos perfil abaixo na faixa da praia, surgindo assim, bancos de areias e cavas na zona de antepraia, sucedendo ainda correntes de retorno (PAULA, 2013).

A vegetação se caracteriza por ser psamófila (psamobiomas), ou seja, que tem "preferência" por solos arenosos, envolvendo espécies arbóreas, arbustivas e rasteiras; os helobiomas são formados por manguezais desenvolvidos em faixas de solo lodoso sujeito à salinidade emitida pelo ingresso das marés (AB'SÁBER, 2001). Existem, ainda, réstias de vegetação halófila-psamófila, que habitam meios arenosos ricos em sal e várzeas que se estendem pelos leitos dos principais rios, tendo como espécie de maior ocorrência a Copernicia prunifera (carnaúba) (IBAMA, 1998). 
Segundo o IBAMA (1998), encontram-se nesse litoral seis unidades geoambientais que apresentam dinâmicas e complexidades diferenciadas, refletindo a composição de materiais trabalhados por processos de acumulação de sedimentos transportados pelos rios que se combinam com as ações marinha e eólica. Estas unidades são classificadas como: faixas de praias e campos de dunas móveis, campos de dunas fixos e semifixos, planícies fluviomarinhas, planícies lacustres e fluviolacustres, planícies fluviais e tabuleiros.

Dessa forma, apesar do litoral do Piauí corresponder ao de menor extensão em relação aos demais estados brasi- leiros, representando apenas $0,89 \%$ do total, este apresenta características singulares. Isto porque essas condições conformaram uma compartimentação diferenciada em decorrência da atuação de variáveis condições ambientais durante o Quaternário (LIMA, 1987; CAVALCANTI, 2000).

Assim, considerando que os materiais e os processos se espacializam, via de regra, dando conformação às feições de relevo e são, ao mesmo tempo, por elas influenciados, neste trabalho se chegou à proposição de classificar a faixa do litoral do Piauí em três compartimentos distintos: Litoral Deltaico, Litoral Dunoso e Litoral Estuarino (Figura 2).

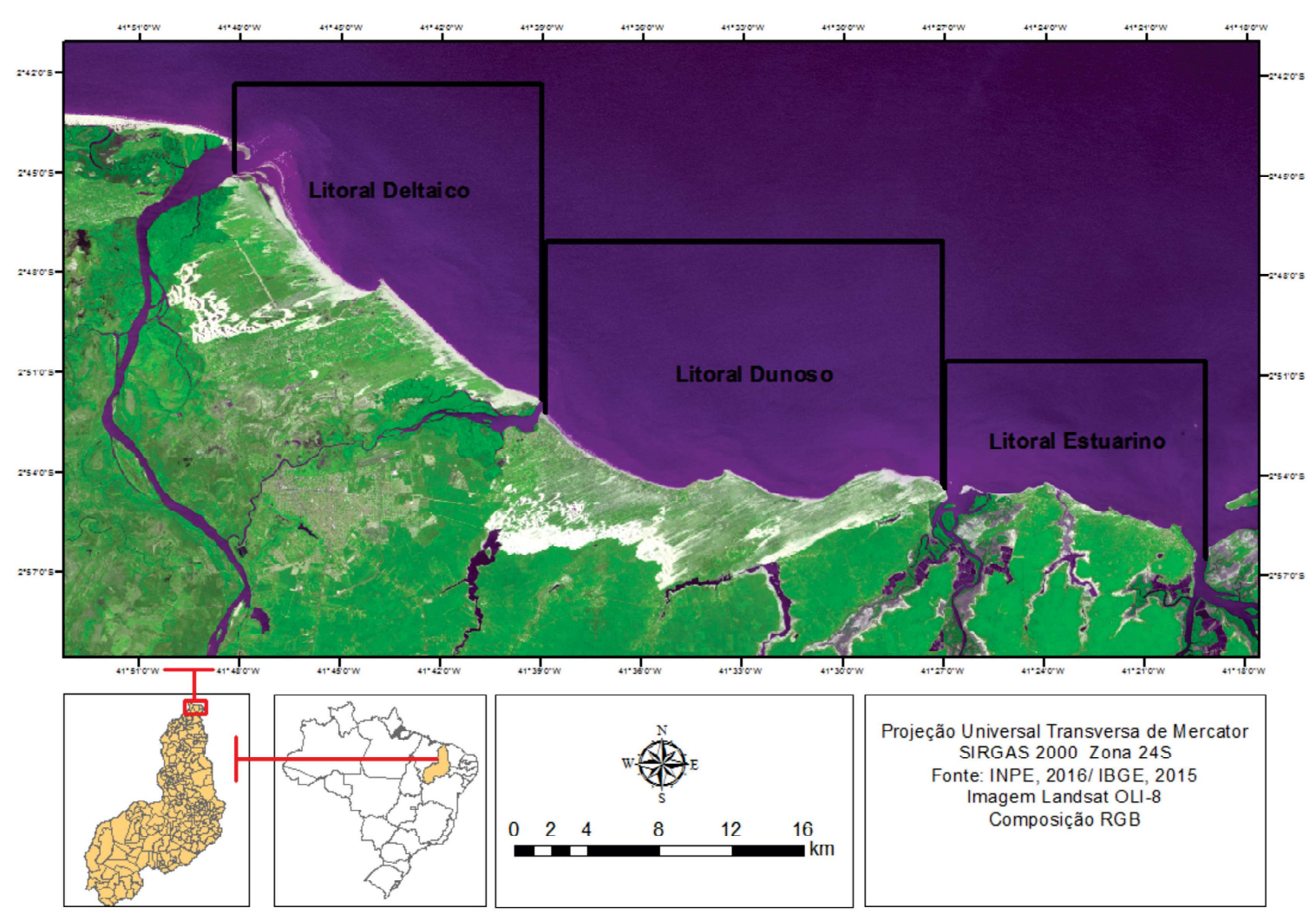

Figura 2 - Localização dos Compartimentos Geomorfológicos do Litoral do Estado do Piaui. Fonte: Elaborado pelos autores (2017).

\section{Litoral Deltaico}

O compartimento Litoral Deltaico se inicia na desembocadura principal do rio Parnaíba, na baía das Canárias, no limite do Piauí com o Estado do Maranhão, e se estende para o leste até a desembocadura do rio Igaraçu, na baía de mesmo nome. O rio Igaraçu é um dos quatro canais secundários do Paranaíba que, justamente com o canal principal deste rio, formam o grande delta em mar aberto. E é a partir do Igaraçu, para o sentido oeste, que se inicia o delta. É deste ponto para a dire- ção leste que a costa piauiense torna-se diferenciada, formando uma grande enseada, onde a acumulação de sedimentos é mais preponderante.

Este trecho tem aproximadamente $23,40 \mathrm{~km}$ de extensão. Nele se observa a formação de uma enseada acentuada da Barra das Canárias a Pedra do Sal, sendo esta mais retilínea entre a Pedra do Sal e a desembocadura do rio Igaraçu

A característica principal dessa faixa litorânea é a presença do delta do rio Parnaíba, sendo o maior delta 
das Américas em mar aberto e o terceiro maior sistema deltaico do mundo (DINIZ et al., 2016), justificando, portanto, a denominação de Litoral Deltaico.

O delta do Parnaíba apresenta extensas planícies fluviomarinhas cortadas por uma rede de canais distributários, formadores de inúmeras ilhas, como se observa em imagens Landsat e do Google Earth. Esses canais ora se apresentam meandrantes, sinuosos, ora anastomosados e, ainda, em pequenos segmentos retilíneos e em forma de canais abandonados. Desenvolvem-se nas margens dos canais fluviais e em suas ilhas, extensas áreas de manguezais, com uma vegetação altamente especializada, sendo resultado de processos de acumulação fluviomarinha, dominada por um clima quente e úmido. Essas ilhas deltaicas apresentam também áreas recobertas por amplos campos de dunas móveis que se deslocam para seu interior, como resultado da sedimentação eólica, possuindo principalmente orientação NE-SW. Todavia, em certos trechos o ritmo da movimentação das dunas é reduzido ou barrado por vegetação rastejante e arbustiva que promovem a fixação das dunas de forma natural. Assim, este ambiente está sujeito a uma dinâmica excessivamente forte devido a sua complexidade, resultado das atividades construtiva e destrutiva das marés, ventos e dos rios que se somam os movimentos do piso crustal recentes. Caracterizando estas interações como fortemente instável (BRASIL, 2001).

O litoral desta seção é formado por várias praias arenosas, conhecidas como: Barra das Canárias, Maceió, Cotia, Pedra do Sal, Eólica e Ostras. Devido ao transporte de material sedimentar ter contato perpendicular à linha da costa, por apresentar o sentido NW-SE, torna esta área mais favorável a sedimentação (CAVALCANTI, 2000). Outra característica marcante das praias do litoral deltaico é sua composição sedimentológica, composta também por elevados teores de siltes e argilas, reflexo da contribuição fluvial do rio Parnaíba, diferente daquelas do Litoral Dunoso.

Essas são praias expostas, com declive íngreme resultando em estreita face de praia e com largura de até $100 \mathrm{~m}$ na maré baixa. Este setor do litoral é altamente influenciado pelo promontório de Pedra do Sal que provoca difração a jusante e recuo do litoral, conforme destacam Paula et al. (2016).

O promontório de Pedra do Sal, localizado entre as praias da Pedra do Sal e Eólica, corresponde a um afloramento cristalino, formado por dois rochedos: um junto à costa e outro ao largo. $\mathrm{O}$ rochedo que fica junto à costa, é formado por um corpo de rocha granítica que se destaca em meio aos sedimentos mais recentes da praia e as águas do oceano Atlântico, onde se encontra um farol construído em 1873 (Figura 3). Neste setor também é possível identificar grandes dunas, paleodunas e terraços fluviais e fluviomarinhos.

No litoral deltaico forma-se o arquipélago de Santa Isabel, composto por canais entrelaçados, furos e diversas ilhas e ilhotas. Na Barra das Canárias se destacam as ilhas: Trindade, Batatas, Goiabeiras, Morros, Camarço e Santo Estevão. Na Barra do Igarassu encontram-se as ilhas: Palha, Cágado, Ferreira, Chafariz, Bom Jesus, Costa, São Roque e Meio. Entre as duas barras a Ilha Grande de Santa Isabel se destaca por ser a maior deste arquipélago, com $240 \mathrm{~km}^{2}$, de forma nitidamente triangular, com a maior face voltada para o atlântico, outra delimitada pelo Igaraçu e a terceira pela barra das Canárias (Figura 4).

Este compartimento, controlado principalmente pela gênese fluvial do rio Paranaíba e conformação do maior delta das Américas, abrange uma área complexa de planícies fluviomarinhas, periodicamente inundáveis com sedimentos mal selecionados e ricos em matéria orgânica de origem continental e acréscimos de sedimentos marinhos. Ocorre a presença de gleissolos tiomórficos, revestidos por manguezais, com padrão fisionômicos e florísticos variados (IBAMA, 1998). Também de grande importância são os campos de dunas móveis, paleodunas e campo de deflação eólica. O campo de dunas móveis barcanoides que ocorrem neste setor tem uma direção preferencial NE-SW, ocorrendo principalmente no interior da Ilha Grande de Santa Isabel, penetrando entre 5 a $8 \mathrm{~km}$ e separados da faixa litorânea por campos de paleodunas de $5,5 \mathrm{~km}$ de largura. $\mathrm{O}$ avanço das dunas móveis sobre as planícies fluviomarinhas, causa instabilidade geomorfológica e diminui a produtividade biológica consequentemente.

Neste compartimento encontram-se dois municípios: Ilha Grande, com uma população de 8.914 habitantes, e Parnaíba, o segundo município mais populoso do Estado do Piauí, com 145.705 habitantes, depois de Teresina capital do Estado, que apresentou 814.230 habitantes em 2010 (IBGE, 2010). 
As suas potencialidades se referem ao ecoturismo, extrativismo, pesquisas científicas, pesca, carcinicultura, lazer, além do seu potencial paisagístico composta por praias e ilhas fluviais e biodiversidade elevada.
Quanto aos impactos socioambientais locais, estes se relacionam a degradação dos manguezais, poluição dos rios com os despejos de efluentes e diminuição de espécies de peixes e crustáceos pela pesca predatória.

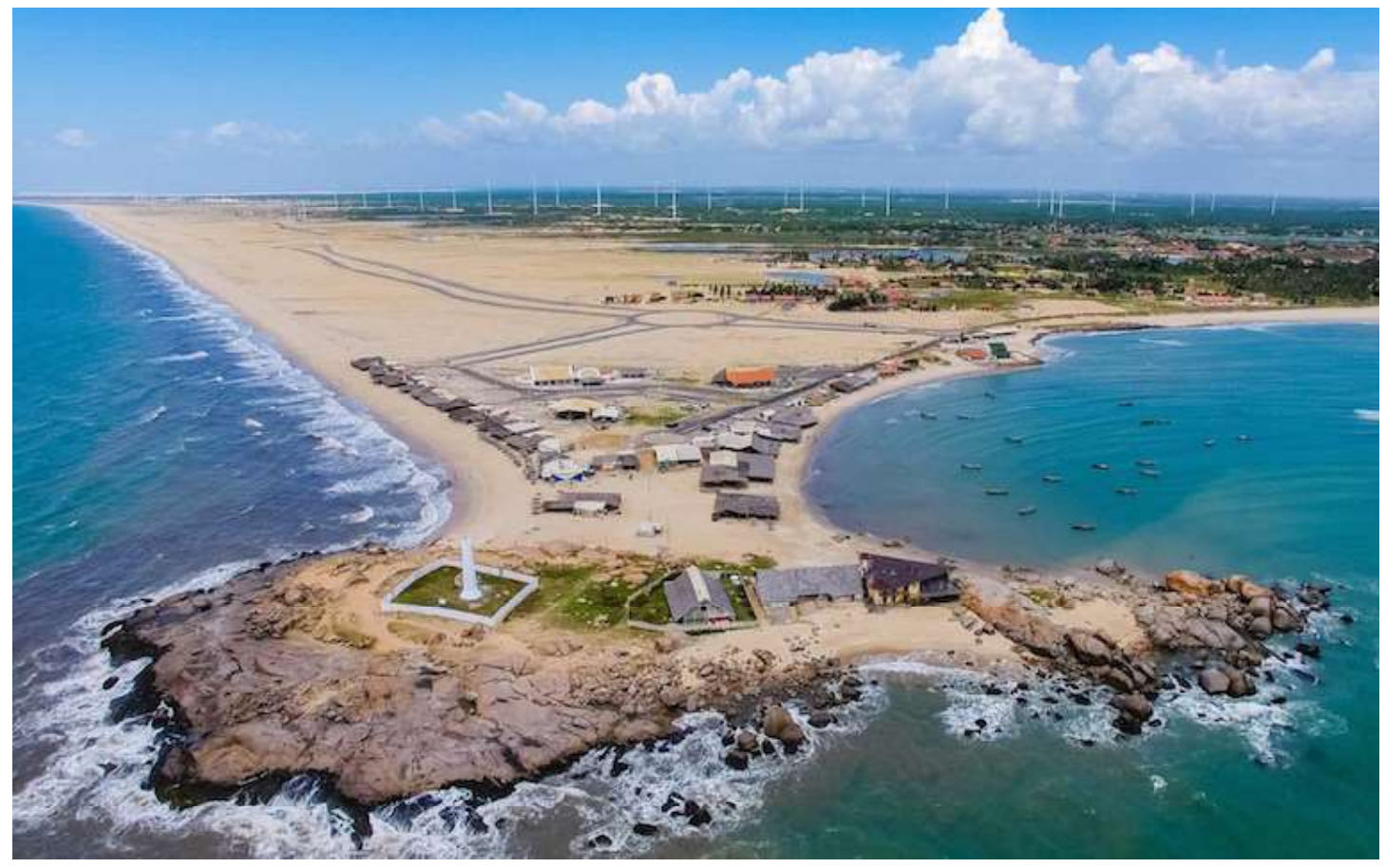

Figura 3 - Praia de Pedra do Sal, município de Parnaíba, Piaui. Fonte: http://panoramacultural.com.br/rota-das-emocoes/.

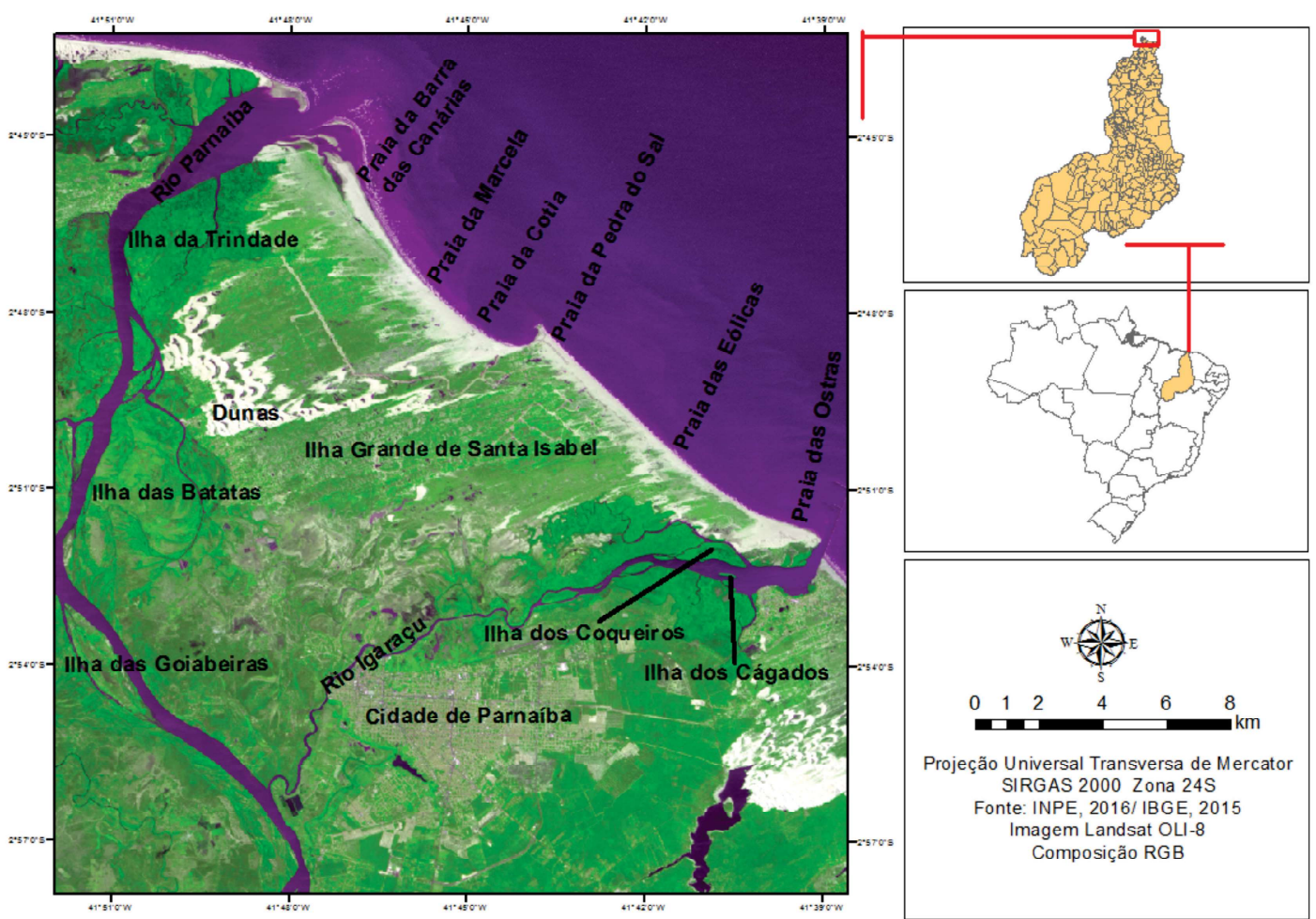

Figura 4 - Mapa do Litoral Deltaico do Piaui, destacando as praias e as ilhas. Fonte: Elaborado pelos autores (2017). 


\section{Litoral Dunoso}

O compartimento Litoral Dunoso se inicia na desembocadura do rio Igaraçu, na baía de mesmo nome, e se estende para leste até a Ponta do Anel, na desembocadura dos rios Cardoso e Camurupim. Este segmento possui aproximadamente $25,91 \mathrm{~km}$ e duas enseadas bem proeminentes: uma partindo da foz do rio Igaraçu até Itaqui e a outra de Itaqui a Carnaubinhas.

A configuração da costa apresenta o sentido SW-NE tornando-o mais propício à acumulação de sedimentos, auxiliando na formação de dunas dissipadas pela ação eólica (CAVALCANTI, 2000).
$\mathrm{Na}$ desembocadura do rio Igaraçu, município de Luís Correia, localiza-se o único porto marítimo do Piauí, ainda inacabado, de onde segue essa faixa litorânea pelas praias arenosas (Figura 5) constituídas por sedimentos quartzosos finos a médio, diferentemente dos sedimentos do litoral deltaico que possuem altos teores de siltes e argilas em sua composição, reflexo da contribuição fluvial do rio Parnaíba, de Atalaia (onde fica um farol), Peito de Moça, Barro Preto, Coqueiro, Itaqui, Arrombado, Carnaubinha, Maramar e Macapá. Em muitas destas praias afloram na maré baixa uma linha de recifes areníticos à linha da costa.

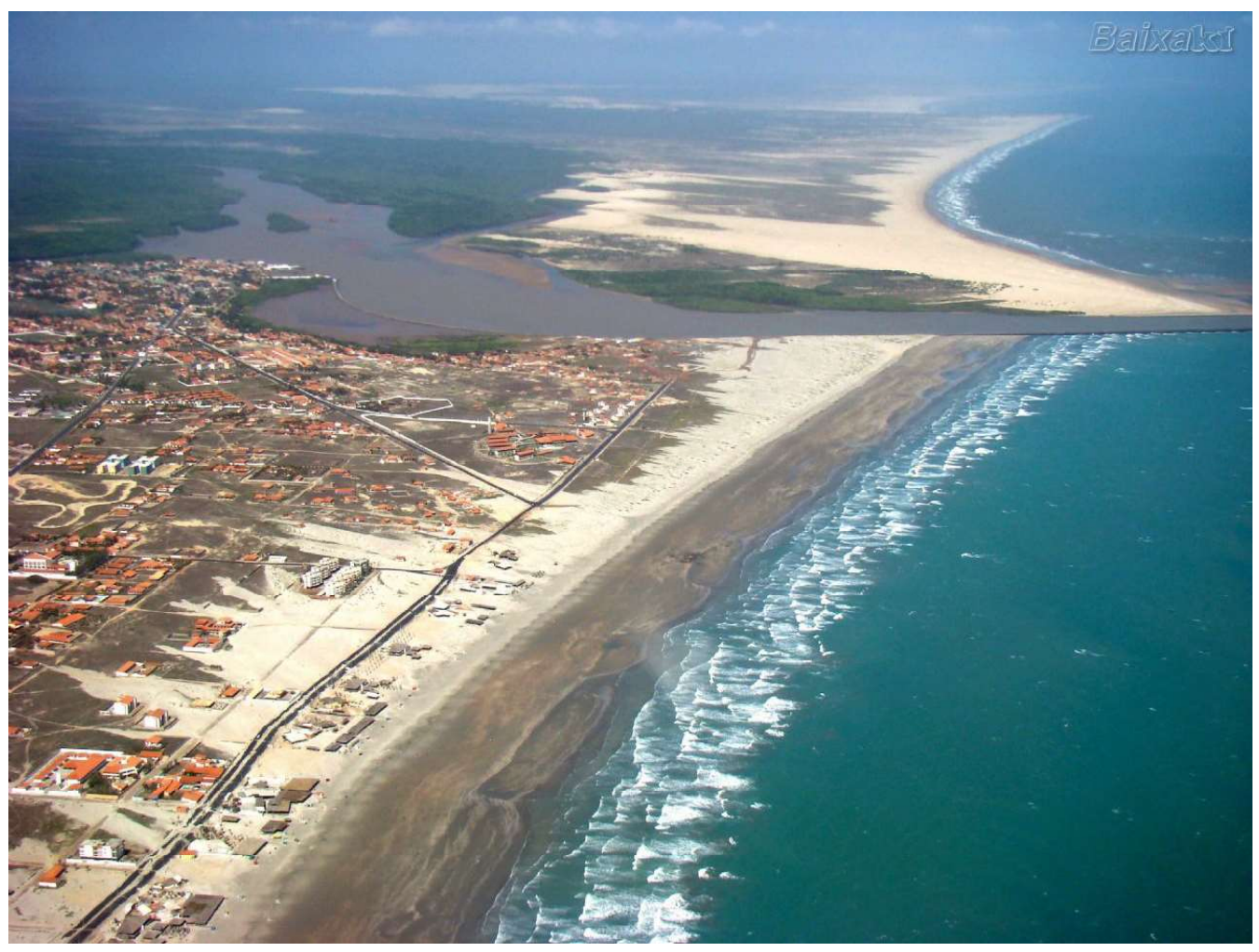

Figura 5-Praia de Atalaia e Foz do rio Igaraçu. Fonte: https://www.baixaki.com.br/papel-de-parede/30947-praia-de-atalaia-luiz-correia-piaui.htm.

As praias deste setor do litoral são urbanizadas e muito frequentadas por turistas, visitantes e veranistas. Atalaia é uma praia exposta com baixa inclinação e com até $450 \mathrm{~m}$ de largura na maré baixa, sem indícios de erosão e com considerável transporte eólico de areia para os campos de dunas. As demais praias apresentam altos índices de erosão, tendo como principais fatores: a ocupação e represamento de sedimentos costeiros, processos de difração de ondas e encosta íngreme da praia. Estas possuem uma estreita face praial, que atingem 100 m na maré baixa (PAULA et al., 2016).
Este setor do litoral é caracterizado principalmente pela presença singular de campos de dunas ativas, correspondendo a depósitos arenosos paralelos à linha de costa, com cotas variando de 5 a $40 \mathrm{~m}$, superpostos ao Grupo Barreiras (Figura 6), sendo produzidos pelo transporte e deposição de partículas pelo vento, com assimetria justificada pela inclinação maior no lado sotavento em relação ao lado barlavento (SOUSA, 2015). As dunas desse litoral são constituídas totalmente por areias claras, de granulometria fina e muito bem selecionadas, que em sua maioria apresentam formato do tipo barcanas, apresentando cristas 
em forma de meia-lua, com a face convexa voltada para barlavento e a côncava para sotavento (BRANCO et al., 2003 apud SOUSA, 2015) (Figura 7). A diferença marcante entre as dunas do litoral deltaico e dunoso é a coloração de suas areias, pois, no primeiro se apresenta em tons mais amarelados, decorrente do volume de sedimentos fluviais trazidos pelo rio Parnaíba, em relação as do litoral mais a leste, as quais são mais claras.

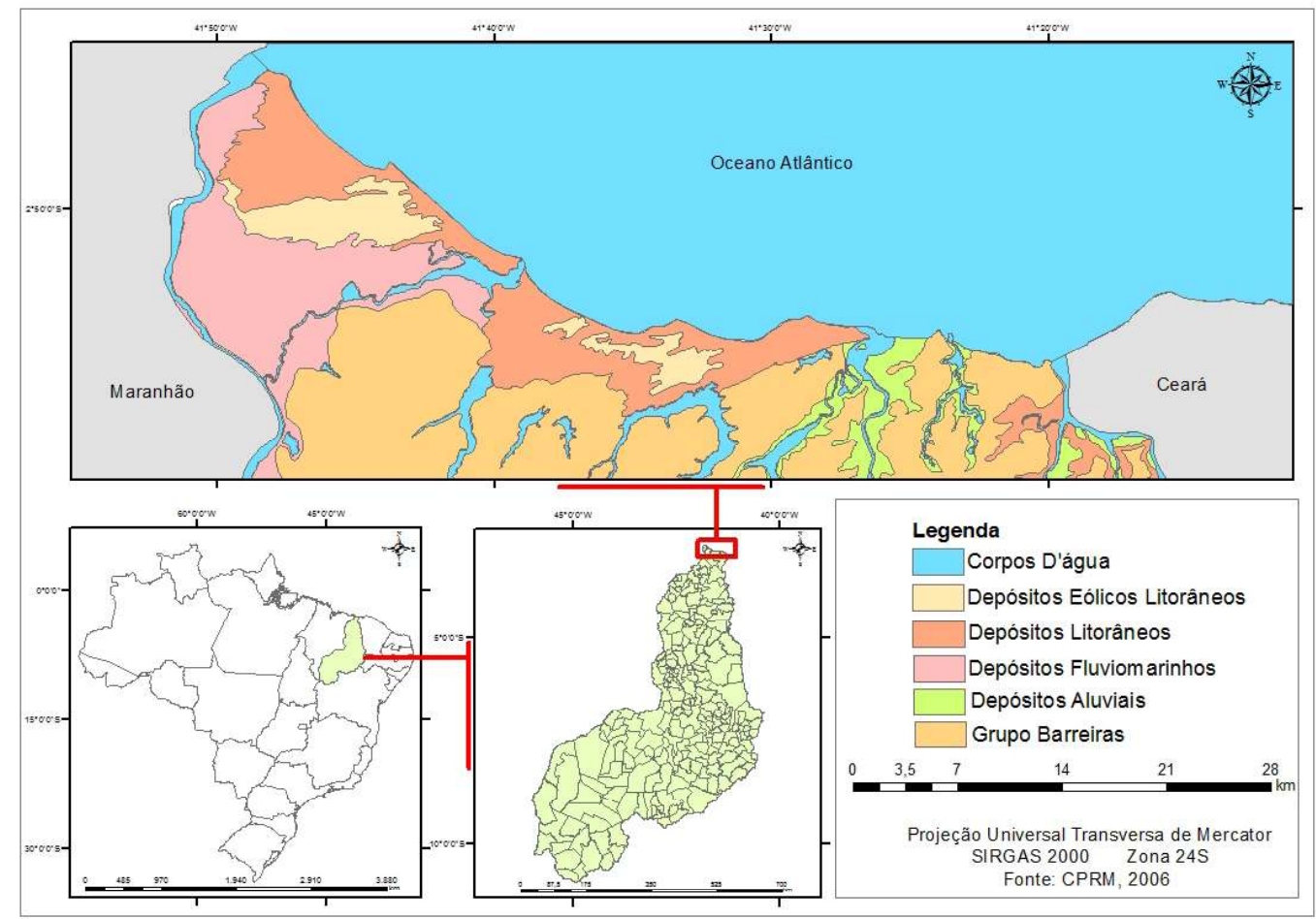

Figura 6 - Geologia da área de estudo. Fonte: Elaborado pelos autores (2019).

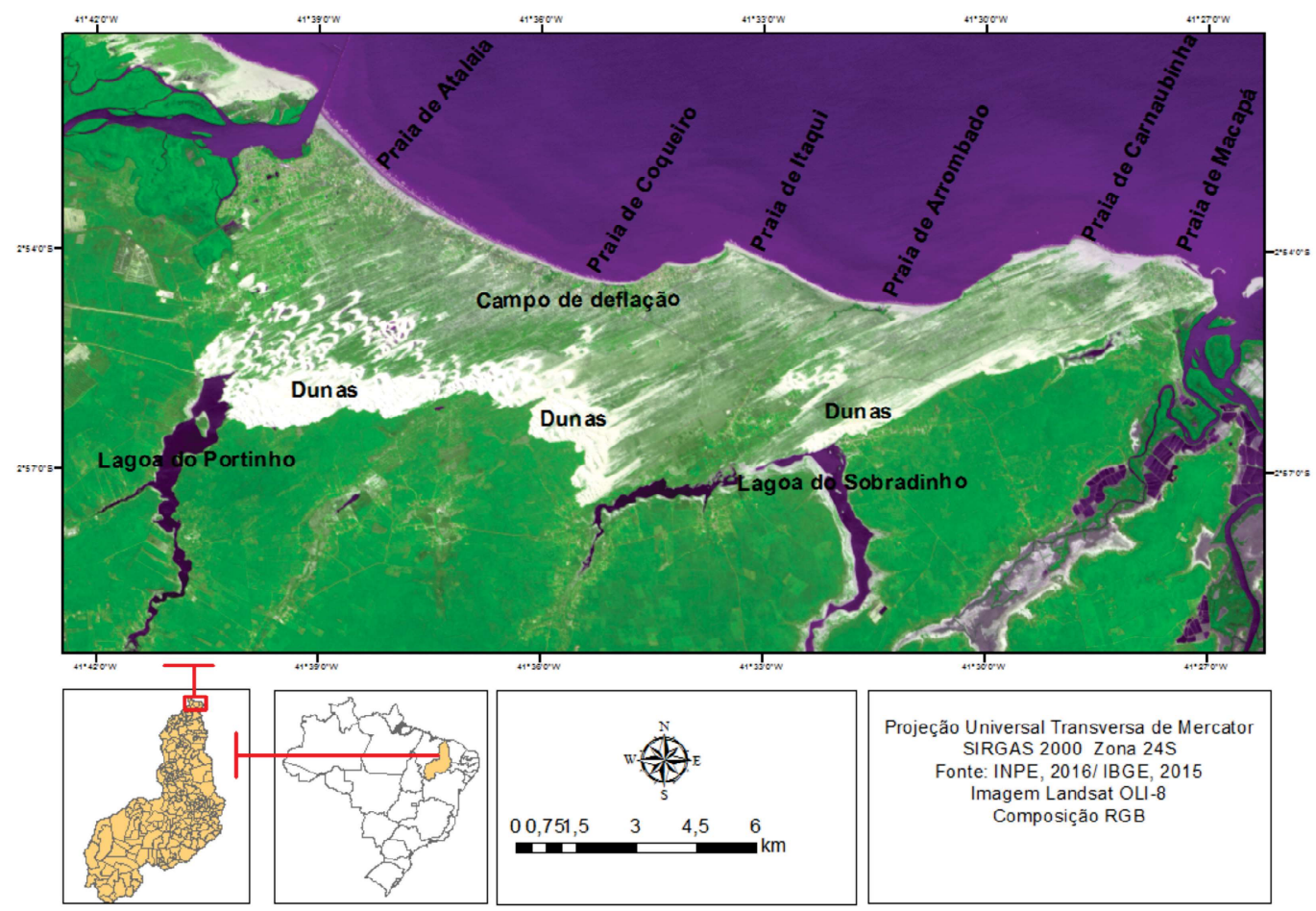

Figura 7 - Mapa do Litoral Dunoso do Piauí, destacando as praias e os campos de dunas. Fonte: Elaborado pelos autores (2017). 


\section{Litoral do Estado do Piaui: Proposta de Compartimentação}

O principal elemento impulsionador dos processos costeiros são os ventos alísios de Nordeste, auxiliados pela ação das brisas locais e morfologia da costa, que conduzem as areias da faixa de praia para o continente, formando campos de deflação e de dunas. A migração das dunas em direção ao continente barra e assoreia os cursos dos rios que desaguam no litoral, formando lagoas costeiras. Nesse setor encontram-se várias lagoas fluviais originadas pelo barramento dos rios pelas dunas móveis, sendo as maiores a do Portinho e do Sobradinho. Nessas áreas vão se conformando planícies lacustres e fluviolacustres, constituídas por faixas de acumulação de sedimentos areno-argilosos, ponderadamente mal selecionados, ocupando a borda de lagoas de origem fluvial, freática ou mista, além de áreas de acumulação inundáveis durante o período chuvoso. Aí os solos que vão se formando são os planossolos e aluviões revestidos por vegetação cujo padrão fisionômico e florístico corresponde ao da mata ciliar com predominância de carnaúbas (IBAMA, 1998).

Outra importante característica do litoral piauiense são os campos de deflação eólica. Estes constituem áreas aplainadas constituídas de sedimentos eólicos em laminações lisas, bem como estratificações cruzadas. Associadas a estas, são representativos os campos de dunas fixas e semifixas, dispostas à retaguarda da faixa de praias e campos de dunas móveis (Figura 8).

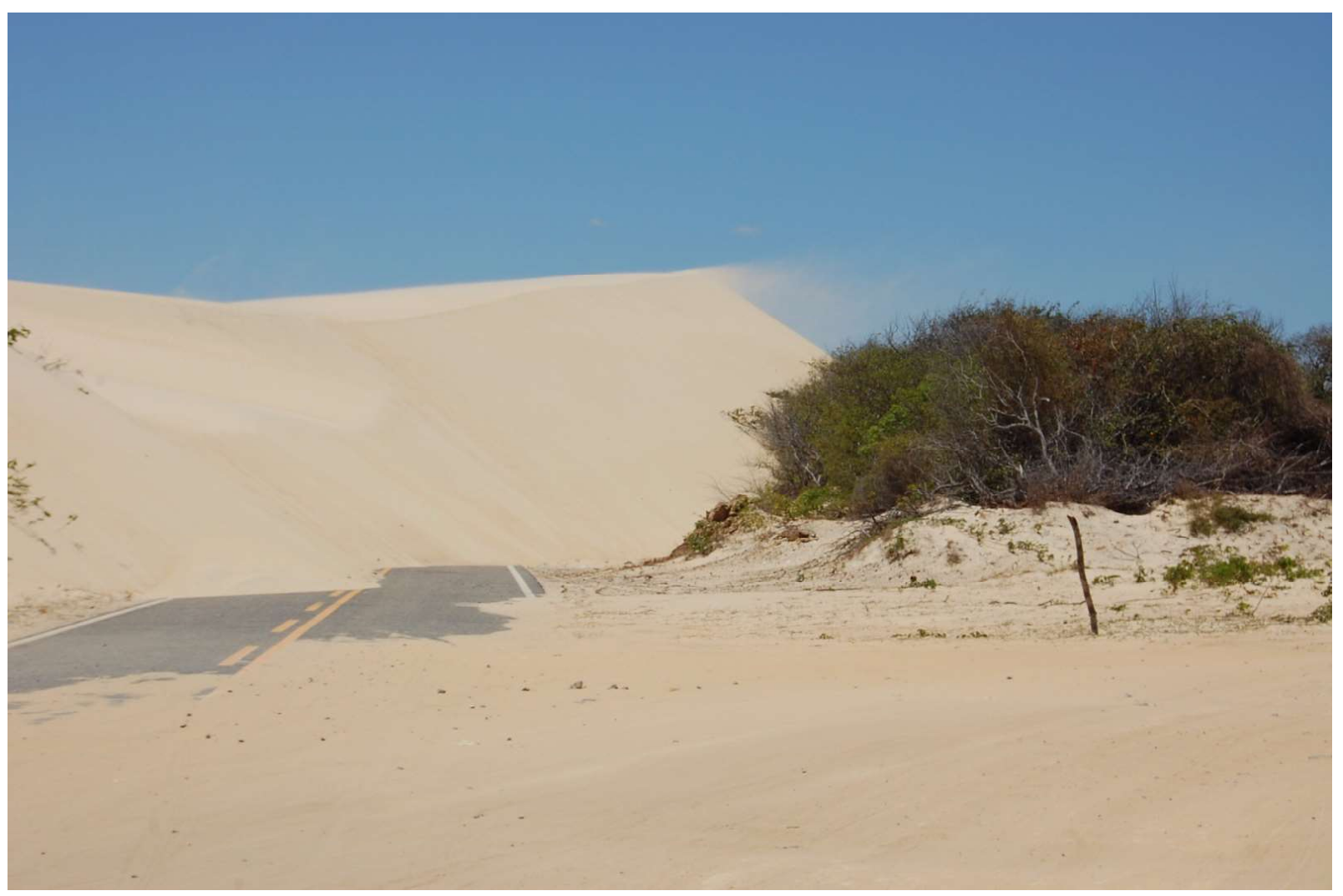

Figura 8 - Duna móvel, limite entre os municípios de Parnaíba e Luís Correia, Piauí. Fonte: Fotografia dos autores (nov., 2016).

Uma condição essencial à fixação de dunas litorâneas corresponde ao desenvolvimento incipiente do solo que, por sua vez, favorece a fixação de cobertura arbóreo-arbustiva (dunas fixas) ou de uma camada de gramíneas e tufos descontínuos (dunas semifixas) (IBMA, 2008).

Luís Correia é o único município que se encontra nesse segmento do litoral, com uma população de 28.406 habitantes (IBGE, 2010). Suas principais potencialidades em termos de uso estão relacionadas ao ecoturismo, pesca, recursos hídricos subterrâneos e lacustres, lazer e ocorrência de minerais pesados e areias monazíticas.

Já os impactos principais na área estão condicionados pelo desmonte ou interrupção das dunas por ocupações desordenadas, poluição dos rios. Também 
ocorrem nessa área processos erosivos ativos, erosão marinha e recuo da linha de costa, retirada da cobertura vegetal das dunas com retomada e aceleração da erosão e trânsito habitual de areias, que aterram mangues, estradas e áreas urbanizadas, além de assorear os rios.

\section{Litoral Estuarino}

O compartimento Litoral Estuarino se inicia na Ponta do Anel, na desembocadura dos rios Cardoso e Camurupim, e se estende para leste até a barra dupla dos rios Ubatuba (Piauí) e Timonha (Ceará), onde começa o litoral cearense. Este compartimento possui aproximadamente $16,62 \mathrm{~km}$, sendo bem recortado pela formação de dois estuários principais formados por esses quatro rios e também por pontas que fazem os limites das praias locais.

Como se observa na Figura 9, a característica principal deste compartimento são os estuários. Estes possuem a forma aproximada de um triângulo cuja pequena base se encontra na direção do oceano e o vértice na direção do continente, possuindo um desaguadouro único, oposto ao delta que é constituído por vários braços fluviais.

O compartimento toma o sentido W-E, mantendo a linha da praia processada paralelamente a costa, onde atribui-se setores de menor energia e com dominância de áreas inundáveis de origem fluvial. As planícies fluviais abrangem áreas de inundação dos rios Cardoso/ Camurupim e Ubatuba/Timonha, no qual se formam depósitos aluviais nos canais dos cursos de água e áreas alagáveis relacionadas às correntes fluviais (CAVALCANTI, 2000).

Compreendem superfícies baixas, tipo várzeas, parcialmente inundadas, com solos aluviais eutróficos, planossolos, com inundações e dificuldade de drenagem e sendo estes revestidos por matas ciliares, com predominância de carnaúbas (IBAMA, 1998). Tem destaque, ainda, a presença de grandes manchas de apicuns ou salgados que se formam entre os carnaubais e os mangues dessa área, observados na porção leste do compartimento.

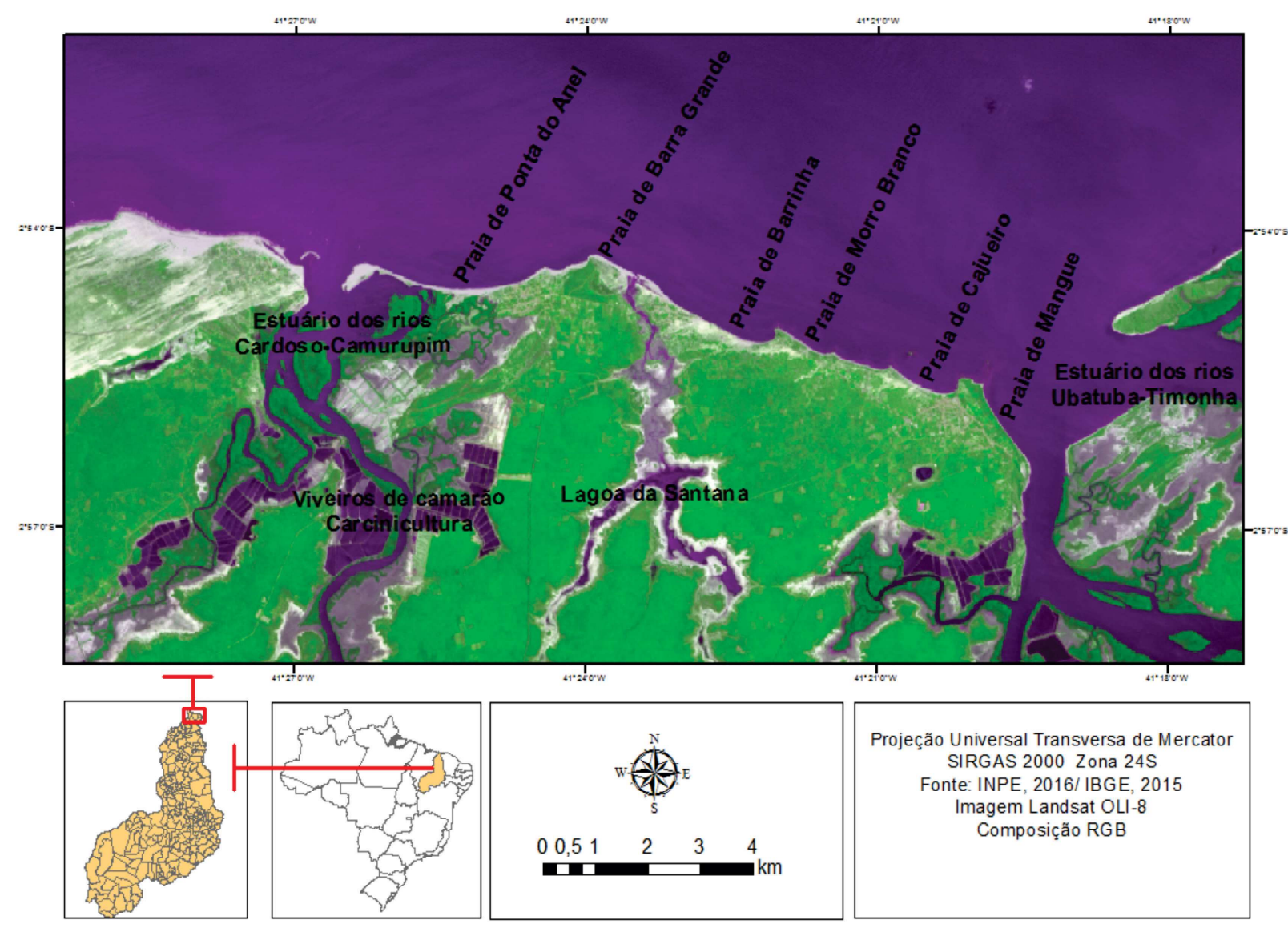

Figura 9 - Mapa do Litoral Estuarino do Piaui, destacando as praias e os estuários. Fonte: Elaborado pelos autores (2017). 
Os rios Cardoso/Camurupim e Ubatuba/Timonha, pela influência que sofreram das regressões e transgressões marinhas ocorridas no Quaternário e principalmente pelo transporte de sedimentos fluviais para o litoral, facilitaram a constituição de barras nas suas desembocaduras por meio de cordões arenosos em sequência (Figura 10). Estes, quando remontados pela ação dos ventos alísios de NE, passaram a formar dunas dissipadas, tendo vegetação pioneira estabilizada de forma limitada (CAVALCANTI, 2000), porém representando pequenos estoques de areias. Esses rios Cardoso/ Camurupim e Ubatuba/Timonha correspondem aos principais sistemas continentais que contribuem para presença de sedimentos da zona costeira desse setor.

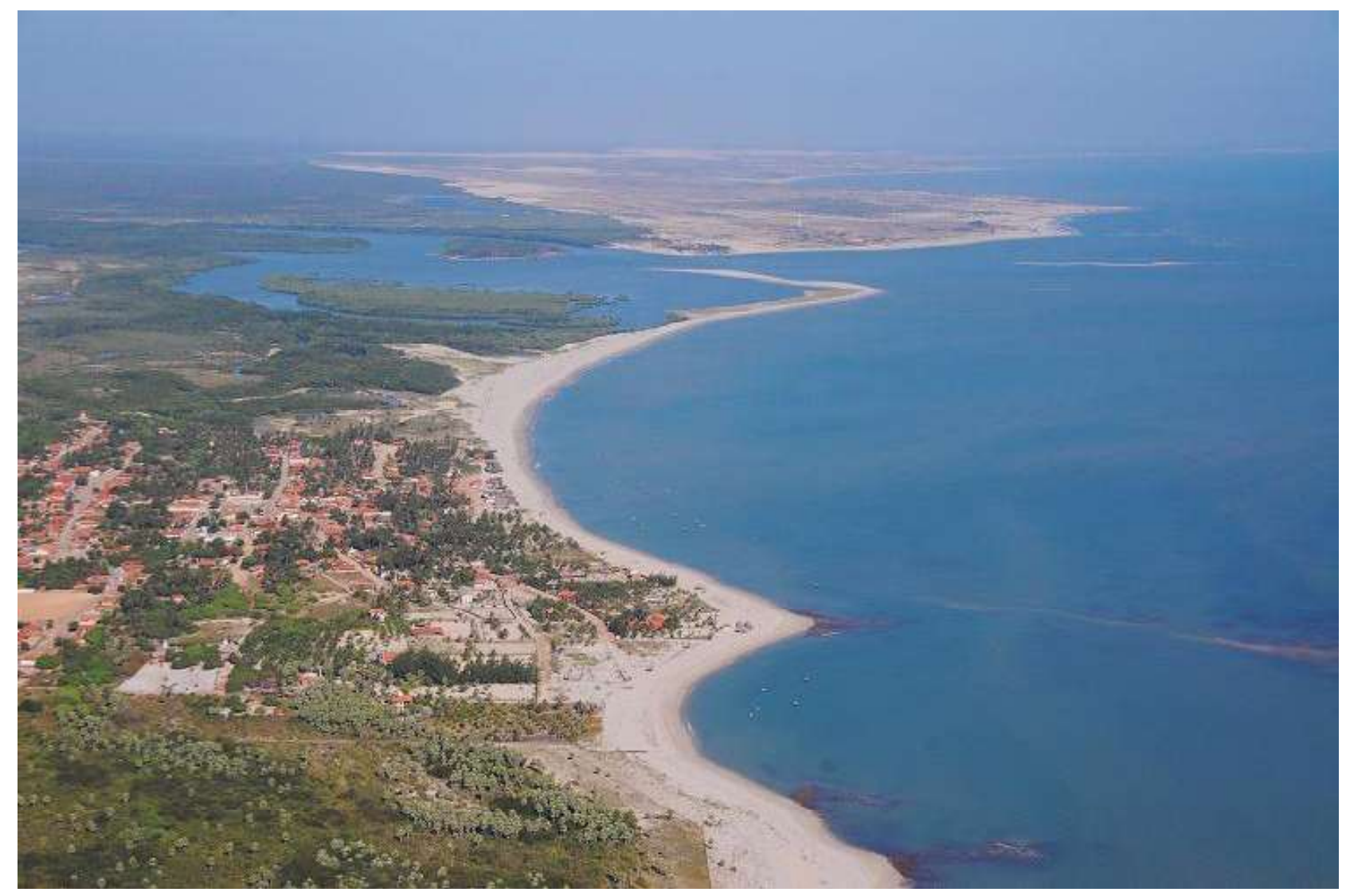

Figura 10 - Barra Grande, município de Cajueiro da Praia, ao fundo estuário dos rios Cardoso-Camurupim. Fonte: http://bonsventosnoticias. blogspot.com/2015/06/.

Neste compartimento do litoral se destacam muitas praias arenosas: Ponta do Anel, Barra Grande, Barrinha, Morro Branco, Cajueiro e Mangue.

Nas praias de Ponta do Anel e Barra Grande, ocorrem processos de difração de ondas estabelecendo mudanças na corrente costeira e a formação de barras paralelas no pós-praia, que são submersas na maré alta, apresentando largura de cerca de $500 \mathrm{~m}$ na maré baixa. Nas praias de Barrinha, Morro Branco, Cajueiro e Mangue ocorre uma maior interação marinha e fluvial (foz do rio Ubatuba), fortemente influenciada pela descarga do rio e pelo contato com águas marinhas geradoras de sedimentos pelíticos que formam um sistema tidal plano colonizado por várias algas.
Apresentando substrato formado majoritariamente de areia muito fina com altas porcentagem de argila e silte, ainda existe cascalho esparso com sedimentos biodetríticos; estas praias são reflectivas com um terraço de $550 \mathrm{~m}$ na maré baixa (PAULA et al., 2016).

Nesta área ainda é possível visualizar parte do tabuleiro litorâneo, abrangendo em direção da linha de costa uma superfície com caimento topográfico, este aflorando na praia do Cajueiro, que conforma uma falésia de $1,5 \mathrm{~m}$ de altura de coloração avermelhada e amarelada e terraço de abrasão (SILVA; LIMA, 2018).

Neste setor se encontra apenas o município de $\mathrm{Ca}$ jueiro da Praia com uma população de 7.163 habitantes 
(IBGE, 2010). Este é, portanto, o segmento litorâneo piauiense de menor ocupação humana.

Com relação às potencialidades, abrange desde atividades agrícolas, minerais, extrativistas, pecuária e pesca até atrativos turísticos. O destaque econômico se deve à carcinicultura, com presença de vários tanques que são utilizados como viveiros (Figura 11).
Os principais impactos socioambientais neste compartimento devem-se a degradação da mata ciliar, que acarreta processos erosivos que assoreiam os rios, a poluição dos rios, a salinização dos solos, as cheias e inundações decorrentes da baixa permeabilidade dos solos e a carcinicultura, atividade que polui as águas oceânicas e degrada mangues e apicuns.

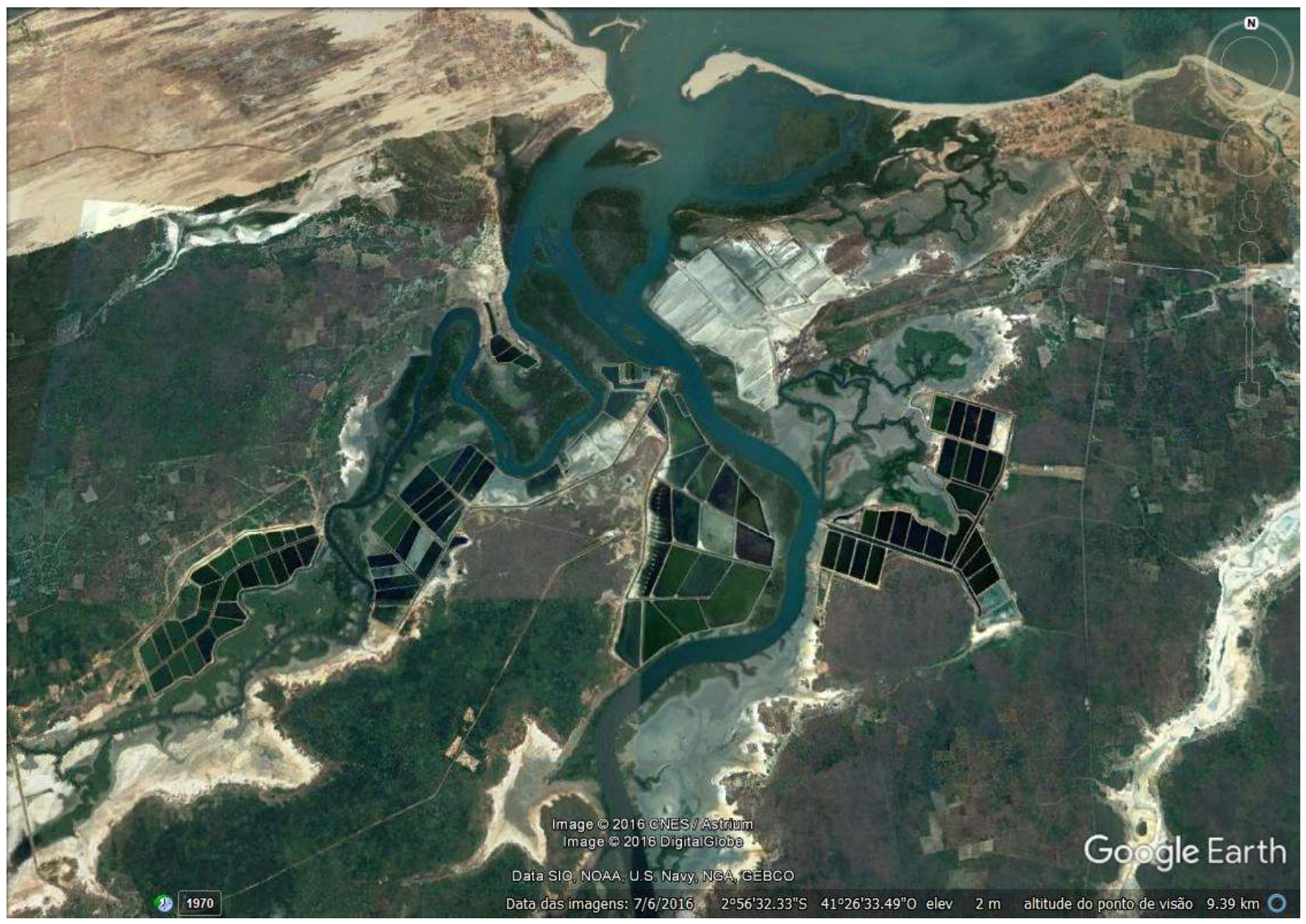

Figura 11 - Imagem de tanques destinados a criação de camarões no estuário dos rios Cardoso/Camurupim, limite entre os municípios de Luís Correia e Cajueiro da Praia, Piaui. Fonte: Google Earth, data da imagem 07/06/2016.

\section{Considerações Finais}

O litoral corresponde a uma área de complexas e rápidas mudanças naturais que se refletem principalmente em feições geomorfológicas distintas, oriundas de processos morfogenéticos e mofordinâmicos. Estes formam e transformam paisagens que geralmente apresentam belezas cênicas, porém são vulneráveis às modificações introduzidas pela ação humana.

Neste sentido, a compartimentação de faixas litorâneas se constitui um dos instrumentos de gestão desse espaço, uma vez que a exploração de seus recursos poderá contribuir para o desenvolvimento socioeconô- mico das populações locais.

Tendo em vista que essa faixa do litoral do Piauí tem sido classificada como parte de grandes compartimentos que setorizam o litoral brasileiro, para efeito de maior conhecimento de suas características ambientais e gerenciamento, este estudo propôs uma classificação em três compartimentos distintos: Litoral Deltaico, Litoral Dunoso e Litoral Estuarino. Isto porque as compartimentações propostas não contemplam e não especificam as particularidades existentes no menor litoral do Brasil, porém não menos complexo e dinâmico quanto as faixas litorâneas dos outros estados brasileiros. 
A compartimentação é uma importante ferramenta de gerenciamento, pois esta, colabora na tomada de decisão por parte dos gestores, facilitando a compreensão de possíveis mudanças nos graus de estabilidade ou resiliência na zona costeira, o que fornece cenários mais realistas para fins de planejamento de médio e longo prazos.

Ao incorporar a diversidade geomorfológica, a configuração geológica, climática e elementos oceanográficos na avaliação da dinâmica costeira em diferentes escalas, para a determinação dos compartimentos do litoral do Piauí, esta oferece uma estrutura de avaliação dos fluxos de matéria e energia ocorridas no sistema costeiro. Isto promove maior atenção ao cenário natural como base para os planos e decisões de manejo, pois, uma vez que os compartimentos são delineados e avaliados, eles podem ser priorizados para planos de manejo específicos para cada compartimento.

A compartimentação do litoral do Piauí em segmentos específicos poderá auxiliar no compartilhamento de informações sobre riscos futuros, podendo ser rapidamente avaliados, priorizados e geridos com base nos recursos disponíveis, além de desenvolver mecanismos para garantir que as áreas costeiras estejam melhor preparadas para enfrentar desafios futuros impulsionados pelas forças das mudanças climáticas.

Assim, ao tempo em que se amplia o conhecimento da complexidade e dinâmica do ambiente natural de cada setor dessa compartimentação, poderão também ser identificadas potencialidades e limitações de sua exploração socioeconômica. Estes conhecimentos tornam-se, portanto, fundamentais como forma de subsidiar o gerenciamento da faixa costeira do Piauí, na busca do desenvolvimento sustentável.

\section{Referências Bibliográficas}

AB'SABER, A.N. Litoral do Brasil. São Paulo: Metalivros, 2001.

BAPTISTA, J. G. Geografia Física do Piauí. 2a ${ }^{\text {a }}$ Ed. Teresina: COMEPI, 1981.

BRANNER, J. C. Geology of the northeast coast of Brazil. Bulletin of the Geological Society of America, v. 13, n. 1, p. 41-98, 1902.

BRASIL. CPRM/Governo do Estado do Piauí. Mapa Geológico do Estado do Piauí. Teresina: CPRM, 2006.
Ministério do Exército. 1978b. Região Nordeste do Brasil - Parnaíba. Córrego Alegre: Divisão de Serviços Geográficos - DSG. Escala 1:100.000 (Carta plani-altimétrica, Folha SA.24 - Y - A - IV, MI 554).

Ministério do Exército. 1979. Região Nordeste do Brasil - Bitupitá. Córrego Alegre: Divisão de Serviços Geográficos - DSG. Escala 1:100.000 (Carta plani-altimétrica, Folha SA. 24-Y-A-V; MI-555).

. Ministério do Meio Ambiente. Zoneamento ecológicoeconômico do Baixo rio Parnaíba: relatório preliminar - fase de diagnóstico. Brasília-DF, 2001.

CARVALHO, C. M. D. Fisiografia do Brasil. Rio de Janeiro: Francisco Alves, 1927.

CAVALCANTI, A. P. B. Impactos e condições ambientais da zona costeira do Estado do Piauí. 341 f. Tese (Doutorado). Programa de Pós-Graduação em Geografia da Universidade Estadual Paulista. Rio Claro (SP), 2000.

JACKSON JUNIOR, C. W.; BUSH, D. M.; NEAL, W. J. The coastal compartment management plan: using Puerto Rico as a model. SOUTHEASTERN GEOLOGY. V. 46, N.2, March, p. $69-84,2009$.

CPRM. Mapa Geológico do Estado do Piauí. Teresina: CPRM/ Estado do Piauí, 2006. Disponível em: http://www.cprm.gov. $\mathrm{br} /$ publique/media/geologia_basica/cartografia_regional/ mapa_piaui.pdf. Acesso em: 20.02.2017.

DAVIES, J.L. The coastal sediment compartment. Aust. Geogr. Stud. 12, p. 139-151, 1974. DOI: 10.1111/j.1467-8470.1974. tb00270.x.

Diniz, M. T. M.; OliveirA, G. P. de. Proposta de Compartimentação em Mesoescala para o Litoral do Nordeste Brasileiro. Revista Brasileira de Geomorfologia. (Online), São Paulo, v.17, n.3, (Jul-Set) p.565-590, 2016. DOI: 10.20502/ rbg.v17i3.844.

DINIZ, M. T. M.; VASCONCELOS, F. P.; OLIVEIRA, G. P. de; MEDEIROS, D. B. S. de. Geografia costeira do Nordeste: bases naturais e tipos de uso. Curitiba: CRV, 2016.

FEITOSA, A. C; TROVÃO, J. R. Atlas escolar do Maranhão: Espaço geo-histórico e cultural. João Pessoa-PB: Editora Grafset, 2006.

GABAGLIA, F. A. R. As fronteiras do Brasil. Jornal do Comércio, Rio de Janeiro, 1916.

IBAMA. Ministério do Meio Ambiente, Recursos Hídricos e da Amazônia Legal. Plano de gestão e diagnóstico geoambiental 
e sócio-econômico da Apa Delta do Parnaíba. Fortaleza: IEPS/ UECE, 1998.

IBGE - Instituto Brasileiro de Geografia e Estatística. Censo Demográfico 2010 - Amostragem da população, Rio de Janeiro: IBGE, 2011.

LIMA, E. A. M.; BRANDÃO, R. L. Geologia. In: Pfaltzgraff, P. A. S.; Torres, F. S. M.; Brandão, R. L. (Org.). Geodiversidade do estado do Piauí. Recife: CPRM, 2010, p.15-24.

LIMA, I. M.M.F. Relevo do Piauí: uma proposta de classificação. Carta CEPRO. Teresina, v.12, n.2, ago./dez., 1987, p. 55-84. Disponível em: http://iracildefelima.webnode.com. Acesso em: 15 jul. 2016.

LIMA, I. M. M. F. Mapa geomorfológico do Piauí. Carta CEPRO. Teresina. v.12 n.2 p. 55-84 Ago/Dez, 1987.

MUEHE, D. Aspectos gerais da erosão costeira no Brasil. Mercator - Revista de Geografia da UFC, Fortaleza, v. 4, n. 7, p. 97-110, 2005. ISSN 1984-2201.

O Litoral Brasileiro e sua compartimentação. In: CUNHA, S. B. e GUERRA, A. Geomorfologia do Brasil. 8 ed. Rio de Janeiro: Bertrand Brasil, 2012, p. 273-349.

PAULA, J. E de A. Dinâmica Morfológica da Planície Costeira do Estado do Piauí: evolução, comportamento dos processos costeiros e variação da linha de costa. 249 f. Tese (Doutorado). Programa de Pós-Graduação em Ciências Marinhas Tropicais. Universidade Federal do Ceará: Fortaleza, 2013.

PAULA, J. E. de A.; MORAIS, J. O.; BAPTISTA, E. M. de C.; GOMES, M. L.; PINHEIRO, L. de S. Piauí beach systems. In: SHORT, A. D.; KLEIN, A. H. F. (Editors). Brazilian Beach Systems. Austrália: Springer, 2016.
SILVA, C. H. S.; LIMA, I. M. M. F. Falésia de Cajueiro da Praia: testemunho da dinâmica da costa piauiense. In: IV Simpósio de Geografia Física do Nordeste (IV SGFNE). SobralCeará, 2018, 12p.

SILVEIRA, J. D. Morfologia do litoral. In: AZEVEDO, A. Brasil: A terra e o homem. São Paulo: Nacional, v. 1, cap.4, 1968.

SOUSA, R. S. Planície costeira do Estado do Piauí: mapeamento das unidades de paisagem, uso e cobertura da terra e vulnerabilidade ambiental. 139 f. Dissertação (Mestrado). Programa de Pós-Graduação em Geografia. Universidade Federal do Piauí, Teresina, 2015.

TESSLER, M.G.; GOYA, S.C. Processos Costeiros Condicionantes do Litoral Brasileiro. Revista do Departamento de Geografia. São Paulo, n. 17, p. 11-23, 2005. DOI: 10.7154/ RDG.2005.0017.0001.

TEIXEIRA, S. G.; SOUZA FILHO, P. W. M. Mapeamento de ambientes costeiros tropicais (Golfão Maranhense, Brasil) utilizando imagens de sensores remotos orbitais. Revista Brasileira de Geofísica. São Paulo, v. 27, supl.1, 2009. ISSN 0102-261X.

THOM, B.G.; ELIOT, I.; ELIOT, M.; HARVEY, N.; RISSIK, D.; SHARPLES, C.; SHORT, A.D.; WOODROFFE, C.D. National sediment compartment framework for Australian coastal Management. Ocean and Coastal Management. 154, p.103-120, 2018. ISSN: 0964-5691.

TORRES, F. T. P; MARQUES NETO, R; MENEZES, S. O. Introdução à Geomorfologia. São Paulo: Cengage Learning, 2012. 